\title{
Gifted Educational Provisions for Gifted and Highly Able Students in Victorian Schools, Australia*
}

\section{Ofertas educativas para estudiantes dotados y altamente capaces en escuelas de Victoria, Australia}

Received: 02 January 2018 | Accepted: 06 June 2018

\author{
LeONIE KRONBORG \\ Monash University, Australia \\ ORCID: http://orcid.org/0000-0002-7100-2164 \\ Claudia A. Cornejo-Araya ${ }^{a}$ \\ Universidad Católica del Maule, Chile \\ ORCID: http://orcid.org/0000-0002-8054-9487
}

a Correspondence author: E-mail: ccornejoa@ucm.cl

How to cite: Kronborg, L., \& Cornejo-Araya, C. A. (2018). Gifted educational provisions for gifted and highly able students in Victorian schools, Australia. Universitas Psychologica, 17(5), 1-14. https://doi.org/1 0.11144/Javeriana.upsy17-5.gepg

\begin{abstract}
This article summarizes the main educational provisions developed and implemented for gifted and highly able students in Victoria, Australia. It emphasizes the strong influence that different governments have had on policies and guidelines providing for the education of these students. Among the options offered it is possible to differentiate those based on acceleration and high ability grouping. Accelerated learning options include early entry, grade skipping, subject acceleration, Higher Educational Studies program, and International Baccalaureate. High ability grouping includes Select Entry Accelerated Learning programs, select entry high schools, specialized high schools. The identification of students' advanced intellectual and academic needs and the implementation of effective provisions for these students are strongly related to the level of knowledge and attitude that teachers have towards gifted and highly able students. The implications of the current educational provisions are discussed to reflect and promote better guidelines and more research in the field.

Keywords

gifted educational provisions; gifted students; highly capable students; professional development.

\section{RESUMEN}

El presente artículo resume las principales ofertas educativas desarrolladas e implementadas para estudiantes dotados y altamente capaces en Victoria, Australia. Se enfatiza la fuerte influencia que los diferentes gobiernos han tenido en las políticas y lineamientos propuestos para la educación de estos estudiantes. Dentro de la oferta aparecen aquellas basadas en aceleración y agrupación por alta habilidad. Las opciones de aceleración incluyen entrada temprana, aceleración de un nivel y por asignaturas, Programa de Estudios de Educación Universitaria, y Bachillerato Internacional. La agrupación por alta habilidad incluye escuelas secundarias con Programas de Entrada Selectiva y Aprendizaje Acelerado, ingreso selectivo y educación especializada. La identificación de necesidades intelectuales y académicas, y la implementación de
\end{abstract}


estrategias efectivas, están fuertemente ligadas al nivel de conocimiento y actitudes que los profesores tienen hacia ellos. Se discuten las implicancias de la actual oferta educativa para reflexionar y promover mejores lineamientos y más investigación en el área.

Palabras clave

oferta educacional para estudiantes dotados; estudiantes dotados; estudiantes altamente capaces; desarrollo profesional.

\section{Contextualising Gifted Education in Australia and more specifically Victoria ${ }^{i}$}

Gifted and talented students have different educational needs (Knopfelmacher \& Kronborg, 2003), and those needs require to be addressed (The Australian Curriculum Assessment and Reporting Authority [ACARA], 2016). These students have the right to receive the education they need to develop their potential through differentiated educational provisions (Kronborg, 2018a).

Australian gifted education is relatively a new field of study (Moltzen, Jolly, \& Jarvis, 2018). It officially started as a unified body in 1985 with the creation of the Australian Association for the Education of Gifted and Talented [AAEGT] (n.d.). This association emerged as a response to a generalized concern after the $5^{\text {th }}$ World Conference of the World Council for Gifted and Talented Children (WCGTC) hosted in Manila, the Philippines in 1983 (Kronborg, 2002; Moltzen et al., 2018). As a sample of the Australian interest and engagement with gifted education, the AAEGT hosted in 1989 the $8^{\text {th }}$ World Conference of the WCGTC in Sydney, Australia (WCGTC, 2015). Then, in 1992, the AAEGT produced its first journal, Australasian Journal of Gifted Education (Vialle \& Geake, 2002) currently in force publishing two issues each year. After more than 30 years developing knowledge and providing for gifted and talented students, Australia still faces resistance usually related to the importance of egalitarianism, placing a high value on equality and rejecting practices which are considered elitist (Kronborg, 2002, 2018a; Moltzen et al., 2018).

Gifted education in Australia has been grounded in different theoretical perspectives
(Kronborg, 2018a). Gagné's model (1985, 2005, 2008, 2010, 2013, 2018), called Differentiated Model of Giftedness and Talent (DMGT) is the most popular theory that underpins gifted education in Australia (Kronborg \& Plunkett, 2012). According to this model, in its more recent revision, giftedness is defined as "the possession and use of biologically anchored and informally developed outstanding natural abilities or aptitudes (e.g., gifts), in at least one ability domain, to a degree that places an individual at least among the top 10\% of age peers" (Gagné, 2018, p. 165). Moreover, talent "designates the outstanding mastery of systematically developed competencies (knowledge and skills) in at least one field of human activity to a degree that places an individual at least among the top $10 \%$ of learning peers" (Gagné, 2018, p. 165).

Australia has conducted two Federal Senate Inquiries into gifted education $(1988,2001)$. The findings showed a lack of provision for these students, as a consequence, important recommendations were developed (Kronborg, 2002; Vialle \& Geake, 2002). However, these recommendations did not result in fundamental changes throughout Australia (Kronborg, 2018a; Moltzen et al., 2018; Walsh \& Jolly, 2018). Additionally, Australia lacks a national policy about gifted education (Frantz \& McClarty, 2016; Rowley, 2012) and a national program to provide funding (Walsh \& Jolly, 2018). However, the new Australian curriculum emphasizes opportunities to address all students' needs, acknowledging their diversity, including the needs of gifted and talented students (Australian Curriculum, 2018).

In Australia, the State of Victoria has had a strong motivation to address the educational needs of gifted and talented students. According to Gagné's definition (2005), approximately 85,000 gifted students are studying in government, independent and Catholic schools in Victoria (Parliament of Victoria, 2012). The State of Victoria had shown its interest in gifted education when in 1978 the Victorian Association for Gifted and Talented Children [VAGTC] was established 
(Cahill, 1990 as cited in VAGTC, 2016), and in 1981, the first accelerated program commenced at The University High School (2016). During the 1980s, Monash University and the University of Melbourne offered teachers units of study in gifted education at the Masters level (Kronborg, 2002). Additionally, Victoria and Western Australia were the states, which led the way in the field of gifted education launching their first state policies in 1981 (Kronborg, 2002). After this, new Victorian policies were launched, such as Bright Futures in 1995 (Directorate of School Education, 1995), and the most recent strategy called Aiming high: A strategy for gifted and talented children and young people (State of Victoria, 2014), was produced to support gifted students to develop their potential between 2014 and 2019.

Nevertheless, gifted education in Victoria has been highly influenced and shaped by political reasons and socio-cultural forces (Moltzen et al., 2018; Plunkett \& Kronborg, 2007). A new Victorian association for gifted education and talent development was established in February 2018 (L. Kronborg, personal communication, 23 Feb 2018), called Association for Gifted and Talented Education Victoria [AGATEVic], which offers professional learning for teachers and access to AAEGT journal (AGATEVic, n.d.). The purpose of this new association is to offer professional learning in gifted education and talent development based on research evidence to interested teachers in schools and to contribute to the development of gifted education policy in Victoria. AGATEVic has affiliated with the AAEGT, so there is state representation from AGATEVic on the AAEGT Committee.

Having opportunities to improve teacher knowledge about gifted education would help teachers significantly. Essential understanding is required in professional learning for teachers of the gifted and talented because they need specialized teacher development to be able to respond to their students' special requirements (Rowley, 2012). This is important, because as Kronborg (2018a) explains, "gifted education is strongly influenced by the professional training in gifted education available to teachers at preservice and postgraduate levels at universities" (p. 85). This is further discussed in this article.

Having different priorities and emphasis, every Australian department of education through their policies and guidelines influences the way that schools approach gifted education (Kronborg, 2018a). In the same way, Victorian schools have different provisions to support students with additional learning needs. These options come from government schools, independent or private sector and Catholic schools (Walsh \& Jolly, 2018). The educational practice developed in each of these contexts vary depending on the school leadership's interest, knowledge and attitude toward gifted and talented students (Plunkett \& Kronborg, 2007). Next section describes the provisions for gifted and talented students in Victorian schools.

\section{Educational Provisions for Gifted and Highly able Students in Victoria, Australia}

In 2012, Victoria conducted a new Inquiry into the education of gifted and talented students (Parliament of Victoria, 2012). At the conclusion of this inquiry, the Committee determined that "gifted students need to be specifically catered for as a matter of equity" (Parliament of Victoria, 2012, p.53). Its policies have shaped provisions for gifted and talented students in Victoria. When viewing the Department of Education and Training in Victoria's (DET) website, it is possible to find Gifted Education under the idea of supporting students with additional learning needs, which acknowledges their difference in the learning process and promotes the importance of addressing these needs.

Provisions for gifted and talented students in Victorian schools include acceleration, high ability grouping, differentiation, enrichment, among others. This article divides these provisions into two main groups: Accelerated learning and high ability grouping. However, it is important to mention that some of 
these provisions share characteristics for both classifications.

\section{a) Accelerated Learning}

Pressey (1949) defines acceleration as "progress through an educational program at rates faster or at ages younger than conventional" (p.2). Assouline, Colangelo, and VanTassel-Baska (2015) indicate that academic acceleration can be divided into two broad categories: contentbased, when a particular student is accelerated by subject area, staying in the normal grade with same age peers or moving to a different classroom for part of the school day; and gradebased acceleration, when a highly able student is moved into a higher class with older students.

Grade-based acceleration is also known as grade skipping, and it is often thought as the only form of acceleration (Dare, Smith, \& Nowicki, 2016). However, within the classification mentioned above, different authors (Southern \& Jones, 2004, 2015; Southern, Jones, \& Stanley, 1993) have presented types of acceleration showing at least 18 different options.

Different studies have concluded that teacher training and professional development are critical elements for accelerating practices, which have significant influence on teachers' attitudes and the provisions chosen to address their gifted and talented educational needs (Gross, Urquhart, Doyle, Juratowitch, \& Matheson, 2011; Lassig, 2009; Plunkett \& Kronborg, 2011). Also, parents' experiences about acceleration are also critical. Dare et al. (2016) concluded that parents perceive positive academic, emotional and social outcomes from acceleration.

The Senate Committee on gifted and talented educational provisions recommended acceleration as a valid option with positive outcomes (Senate References Committee, 2001). In 2012, the new Inquiry into the Education of Gifted and Talented Students (Parliament of Victoria, 2012) mentioned the importance of acceleration again, in terms of providing information to teachers and schools, and the need for guidelines through new recommendations. Some provisions regarding accelerated learning practice in Victorian schools are an early entry, subject acceleration, year level acceleration, Higher Education Studies Programs, and International Baccalaureate.

\section{Early entry to school}

The Victorian DET stipulates that some gifted children may benefit from starting school or kindergarten at an earlier stage. Having academic strength and being emotionally and socially mature, a gifted kid may be ready to participate in a school-based program before the expected age (DET, 2017a). The DET provides material to facilitate the transition process from home to a formal educational environment.

As has been described in the literature, many concerns are related to this decision, especially regarding maturity, socialization, and academic overload, among others (Assouline, Marron, \& Colangelo, 2014; Rimm, Siegle, \& Davis, 2018). However, other authors affirm that early entrant students can develop a positive adjustment in academic and social terms (Gagné \& Gagnier, 2004). In the same way, Davis, Rimm and Siegle (2011) argue that "without such early admission, many gifted children will underachieve" (p. 128).

\section{Subject acceleration}

Subject acceleration is also known as partial or content-based acceleration (Assouline et al., 2015; Rimm et al., 2018). Subject acceleration allows the students to participate in classes with older classmates for a part of the school day for one or more subjects. Students may move to a different advanced classroom or study higher-level subject content in their own classroom (Assouline et al., 2015). This practice is not associated with extra costs for the school; however, it depends on the school and teacher's flexibility to be implemented (Rimm et al., 2018). Subject acceleration might be an appropriate option for twice-exceptional students, who need support in an area of knowledge, and at the same time need to work at a higher level in 
their area of strength (Rimm et al., 2018) This provision allows the gifted and talented students to be intellectually challenged, and develop basic skills by working with social peers. The main disadvantage is the problem of continuity when it is not developed with a long-term view; the student might need to repeat courses or content (Rimm et al., 2018).

Among the benefits, the DET website mentions positive effects in students' learning, engagement, motivation, and self-esteem, due to them being challenged and taught at a faster rate, which addresses their interests and abilities (DET, 2017b).

\section{Year level acceleration}

Also known as, double promotion or grade skipping (Rimm et al., 2018). Southern and Jones (2015) mention that "a student is considered to have grade skipped if he or she is given a grade-level placement ahead of chronologicalage peers" (p. 9). As it was established in the 2012 Inquiry into the education of gifted and talented students, there are no clear guidelines in Victoria for year level acceleration, leaving this decision to the responsibility of the schools and principals. Similar to early entry, there are some concerns about this option for gifted and talented students, which are also related to apprehensions about their social and emotional development, and the problem of missing important basic skills (Parliament of Victoria, 2012; Rimm et al., 2018).

Nevertheless, there is evidence supporting gifted and talented students as most comfortable interacting with like-minded peers and having positive social outcomes from this form of acceleration (Cross, Andersen, \& Mammadov, 2015; Parliament of Victoria, 2012; Rimm et al., 2018). With grade skipping, "boredom, restlessness, frustration, underachievement, and disruptiveness can be replaced by enhanced motivation, improved self-concepts, and improved study habits and productivity" (Davis et al., 2011, p. 134). The DET established that this option might not be suitable for all gifted and talented students, giving their teachers a critical role in identifying if these students are prepared to skip a grade in intellectual, social and emotional terms (DET, 2017b).

\section{Higher Education Studies Program}

These programs are designed for high achieving students in the Victorian Certificate of Education (VCE), and are organized by universities and the Victorian Curriculum and Assessment Authority (VCAA), offering two types of first-year Higher Education study with an equivalent content, assessment and workload corresponding to at least $20 \%$ of a full-time course. After successful completion, students are allowed to proceed to second-year study in the same discipline. These options are 'Extension' and 'Advanced Standing'. In the 'Extension' study, students take challenging and advanced subjects similar in workload to a VCE study. In addition, the Advance Standing study offers units not available in the VCE curriculum, not being linked to any VCE unit 3 and 4 (VCAA, 2017). Successfully completing Higher Education Studies has benefits for the students in terms of being academically challenged, receiving credits towards an undergraduate qualification, contributing to their VCE as unit 3-4, and contributing to the calculation of their Australian Tertiary Education Rank (ATAR). As it is explained in the VCAA website, schools have the responsibility to provide the right support to their students in terms of the requirements. These programs are taught by university staff, or qualified teachers to teach at the right level of exigence.

\section{International Baccalaureate (IB)}

Offering four different programs ${ }^{\text {ii }}$ for students between 3 and 19 years old. One of these options called Diploma Programme attracts students from the $90^{\text {th }}$ percentile or above, who select six subjects among six subject groups iii to be studied over 2 years, in addition to the core 
elements, and at the end of this time, students are evaluated both internally and externally (Rimm et al., 2018). Additionally, "students who successfully complete an IB high school diploma may receive advanced standing at selected universities worldwide if they perform well on the IB exams" (Assouline et al., 2015, p. 11).

According to the International Baccalaureate website (2017), Victoria has 70 IB World Schools, and 17 of them are offering the Diploma Programme (two state schools, and 15 private schools). Some students in Victoria undertake this program instead of VCE or Victorian Certificate of Applied Learning (VCAL) subjects (Parliament of Victoria, 2012).

\section{b) High Ability Grouping}

Ability grouping is referred to, as "the grouping of students together according to ability instead of age" (Parliament of Victoria, 2012), and high ability grouping of students is also different to streaming students. In general, ability grouping options are divided into three alternatives: Full-time homogeneous grouping, full-time heterogeneous grouping, and part-time or temporary grouping (Rimm et al., 2018). Selective environments have been identified as effective options for gifted and high ability students, especially in high school (Kaman \& Kronborg, 2012), Victoria offers different options where gifted and talented students are grouped according to their high ability level. The high ability grouping options are Select Entry Accelerated Learning programs, selective high schools, and specialist secondary schools.

\section{Select Entry Accelerated Learning (SEAL) programs}

Unique in Vitoria "SEAL programs offer selected students in regular comprehensive government schools the opportunity to complete their secondary education within a class of similar high ability peers, with adjustments in both pace and depth of curricular coverage" (Plunkett \& Kronborg, 2007, p. 76). These programs generally work with groups of 25 selected gifted and highly able students from year 7 to 9 . Every SEAL school has this program in addition to the mainstream classes (Parliament of Victoria, 2012). SEAL students usually participate with mainstream students in subjects such as physical education, and subjects such as art or music, which facilitate their social integration. SEAL programs begin in year 7 and students can complete 4 years in 3 years, learning from an enriched accelerated curriculum (Kaman \& Kronborg, 2012). SEAL students have a wide range of options for their senior years, which may include the completion of additional VCE units, Higher Education Studies Program or early entry to tertiary education (State of Victoria, 2014).

As mentioned above, the first SEAL program started in 1981 at The University High School. Since then, each year tests and interviews are used with selective purposes for applicants studying in year 6. The Academy of Accredited SEAL Schools [TAASS] was formed with a purpose to ensure parents and students about the quality of these programs, as they review them frequently (TAASS, 2017a). There are 25 metropolitan and 13 regional accredited secondary schools with SEAL programs in Victoria (TAASS, 2017b).

\section{Select entry high schools}

These schools provide an enriched environment for academically talented and high achieving students (DET, 2017c; Parliament of Victoria, 2012). According to the information pack provided by DET, students who are in their second year of secondary education, in a government, or non-government school, or as home-schooled students; they are eligible to apply to select entry high schools.

Victoria has four selective high schools for academically able students in Years 9 to 12, an all-girls and an all-boys school located in inner Melbourne, and two coeducational high schools in the south-east and the west of Melbourne (Kronborg, 2018a). In these secondary schools, gifted and highly able students learn alongside 
peers who have a similar academic performance and have experienced teachers who provide the challenge these students need (State of Victoria, 2014). The entrance test consists of a series of aptitude and achievement tests including verbal and numerical reasoning, persuasive and creative written expression, reading comprehension, and mathematics. Applying for these selective high schools is a highly competitive process. The DET is in charge of the selection process for the four selective high schools. This process selects $85 \%$ of the students based on test results, $10 \%$ based on Equity Consideration ${ }^{\text {iv }}$ category, and 5\% based on the Principal's discretion category.

\section{Specialist secondary schools}

Victoria has four specialist high schools that provide outstanding and specialized education for gifted and highly able students in different areas (State of Victoria, 2014). Two of these high schools provide specialized education in science and math and are associated with the University of Melbourne and Monash University (Kronborg, 2018a). The other two secondary schools are focus on music, dance, and visual arts; and sports (Parliament of Victoria, 2012; State of Victoria, 2014).

Also, other opportunities come from private programs, competitions (such as Tournament of Minds, and Olympiads), and University-run programs (Joyce, 2005; Parliament of Victoria, 2012). Furthermore, Catholic and Independent schools also provide for gifted and highly able students. Catholic schools have guidelines provided by each archdiocese, and Independent schools are allow to establish their own policies (Walsh \& Jolly, 2018). The Archdiocese of Melbourne, for instance, has developed the Gifted and Talented Students. A resource guide for teachers in Victorian Catholic Schools (Catholic Education Office Melbourne, 2013), which provides knowledge and resources to cater for gifted and talented students. However, many of the options described above are mainly oriented to secondary students, providing fewer opportunities for the primary sector (Parliament of Victoria, 2012). In recent years, the Victorian DET has been emphasizing educational support for young gifted children in their early years (DET, 2018b).

\section{The Critical Role of Teachers: The Importance of Professional Development}

According to Hirsh (2009) "the term 'professional development' means a comprehensive, sustained, and intensive approach to improving teachers' and principals' effectiveness in raising student achievement" (p.12). Multiple methods and data sources are used to assess and make decisions about the needs of gifted and talented students. Some countries, such as the USA, have standards to guide these processes. These standards define the "essential knowledge and skills that teachers need to acquire to be effective in teaching gifted and talented students in the classroom" (VanTassel-Baska \& Johnsen, 2007, p. 183). This essential knowledge is relevant for teachers of gifted and talented students because they need to respond to their students' special requirements (Rowley, 2012), as Johnsen (2012) stated, "educators need to know the professional standards in their field to maintain high levels of professional competence" (p. 49). The Australian Institute for Teaching and School Leadership [AITSL] established seven standards ${ }^{\mathrm{V}}$ for teachers called Australian Professional Standards for Teachers (AITSL, 2017). These Standards aim for the improvement of teacher quality of all teachers in Australia (AITSL, 2017). These seven Standards can also be applied to teaching gifted students. However, this is not explicitly mentioned (Walsh \& Jolly, 2018). Applying these Standards into gifted education will only be possible if teachers are informed with appropriate knowledge about gifted students' educational needs (Kronborg, 2018b).

In 2015 the American Psychological Association [APA] published a document called Top 20 principles from psychology for PreK-12 teaching and learning (APA, 2015). Subsequently, a new version was published presenting the Top 
20 principles from psychology for PreK-12 creative, talented, and gifted students' teaching and learning (APA, 2017). This document could also be used as a guideline to complement the Australian Standards.

In the USA there is limited funding to develop programs, that is why teachers are often not prepared to teach gifted students (Assouline et al., 2015). In Australia, a similar situation occurs, as additional funding is not provided to teach gifted students. The school budget that is the basis for the education of all students is used to fund the education of gifted students. Principals do not get any extra funding to support gifted students' education (DET, 2018c).

It is well known that teachers have a strong influence on their students' learning (Kronborg, 2018b). Having a positive attitude towards their gifted students is critical to being an effective teacher for them, and teacher development can influence positive changes in teachers' attitudes and perceptions (Lassig, 2009; Kronborg \& Plunkett, 2012). A study of pre-service teachers by Plunkett $\&$ Kronborg (2011), found that after a semester of university study in gifted education their attitudes towards gifted students changed most about high ability grouping and acceleration for gifted students. The lack of knowledge in gifted education can lead to inadequate practices due to the difficulty of understanding gifted students' educational needs (Kronborg, 2018b).

The Senate Inquiry in 2001 acknowledged the importance of teacher development in gifted education. In the same way, the Victorian Inquiry into Gifted Education (Parliament of Victoria, 2012) led to recommendations, which included the need for improved teacher education and training. However, with the change of state government, some of these recommendations have not been implemented (Kronborg, 2018a). One valuable attempt to provide professional development for teachers has been the modules developed by the Gifted Education Research Resource and Information Centre (GERRIC) at the University of New South Wales in Sydney in 2005. GERRIC created six modules of professional development that were produced on CD Rom and sent to every school in Australia
(Joyce, 2005; Kronborg, 2018a). However, it is not required for Australian teachers to undertake specialized training in gifted education, as it is for special needs education (Fraser-Seeto, Howard, \& Woodcock, 2015; Walsh \& Jolly, 2018).

In 2017, the Victorian Department of Education and Training funded research and professional learning in gifted education for a cohort of 30 teachers from Victorian government schools to attend a university professional development program. The teachers who selfselected to participate in the program were working with gifted students or planning to develop a new program for gifted students in their schools (L. Kronborg, personal communication, 30 May, 2018). This professional learning program for teachers evolved from previous professional development cohorts contracted through an enterprising principal of a leading high school with a SEAL program who required professional learning for teachers at her school (Kronborg, 2017). The research was also conducted with the teacher participants who were invited to take part in a study of experienced teachers' knowledge of beliefs, pedagogy, and talent development processes with diverse gifted students (Kronborg, 2017).

Professional development in gifted education should aim to provide information at a theoretical level, but also about how to apply that knowledge in practical scenarios (CabreraMurcia, 2012). This is important because in many cases professional development fails to enrich the practice level, and its impact in the classroom (Watters, 2013). This knowledge will influence teachers' attitudes and decisions about which provisions might effectively address their gifted student's needs (Gross et al., 2011).

\section{Conclusions and Discussions}

The purpose of this article was to summarize the provisions offered in Victorian schools to gifted and highly able students. The State of Victoria in Australia has shown its concern to provide appropriate educational opportunities for gifted and highly able students. These provisions 
had been influenced by political changes, and sociocultural reasons (Plunkett \& Kronborg, 2007).

The government, Catholic and Independent schools in Victoria provide educational options for these students, under guidelines established by the Department of Education, Archdiocese or by their own school (Walsh \& Jolly, 2018). Among the provisions offered in Victoria, it is possible to find accelerated learning options and high ability grouping. Some of the learning accelerated options provide opportunities to start school at an early age, subject and year level acceleration, undertaking of university subjects, and the International Baccalaureate. Additionally, there are options to work with likeminded peers in selective school environments such as SEAL programs and selective high schools, as well as specialist secondary schools focusing on math, science, technology, dance, music, and visual arts. Moreover, other provisions include private programs, competitions, and University-run programs (Parliament of Victoria, 2012).

Despite the options presented, and despite the high-quality provisions offered in some schools the Inquiry into the education of gifted and talented students (Parliament of Victoria, 2012), has shown that "the needs of gifted students are not being met by the Victorian education system" (p. 59). The concern still exists for equal access opportunities, especially for those gifted and talented students living in remote areas (Plunkett, 2018), and in terms of the lower expectations and provisions for students from rural areas, Indigenous and low socioeconomic background (Jarvis, Jolly, \& Moltzen, 2018; Parliament of Victoria, 2012).

The trajectory and the educational provisions for gifted students must be attractive sources of knowledge for international students at a postgraduate level, who undertake units or develop research in gifted education in Victoria, wanting to learn and improve their skills to work with gifted students in their home countries (Kronborg, 2018b). However, it seems like these educational provisions are still not enough to meet the Australian educational standards, to address the academic needs of most gifted students. A significant impediment continues, as there is a consuming societal belief amongst many, that gifted education is elitist, and that gifted students may receive an unfair educational advantage by giving advanced educational options that meet their intellectual needs, as there is a perception that this is going against the national value of egalitarianism (Kronborg, 2002, 2018a).

Educational provisions for gifted and highly able students in Victoria have been focused at a secondary level (Parliament of Victoria, 2012). We firmly believe that these efforts should be maintained and even extended to more government school selective learning environments. For instance, SEAL programs and selective high schools have been catering for many gifted students for some years, yet it would be most appropriate to provide improved educational experiences for more gifted children and adolescents in mixed ability classes. Currently, the Victorian DET has been emphasizing young gifted children. Nonetheless further developments need to be done to support gifted students in primary schools, and more specifically in their late primary years in Victoria.

Gifted students who receive an adequate education have positive effects on their engagement and sense of wellbeing (DET, 2017d). However, when their intellectual and academic needs are not addressed, various negative consequences can affect them, such as boredom, social and emotional effects and underachievement (Parliament of Victoria, 2012). When these negative experiences lead gifted students to leave the system or to be disenchanted with their education, it also has a negative consequence for our society.

A critical factor to remove those issues, and to contribute positively to the education of gifted and talented students, is professional learning (Gross et al., 2011; Plunkett \& Kronborg, 2011). For instance, Monash University is currently offering units in gifted education to pre-service teachers and at postgraduate level (Monash University, 2018). Other universities do have some limited educational options. 
Research has informed us that even though these units are usually electives, pre-service and in-service teachers who undertake these units, acknowledge their importance and critical impact on their future or current practices, concluding that these units should be a compulsory part of their programs (Kronborg \& Meyland, 2003; Plunkett, 2018; Plunkett \& Kronborg, 2011).

Increasing the options for professional development, providing clear guidelines for implementing different strategies, and assessing the effectiveness of implemented programs, will contribute to understanding the field of gifted education as a strategic area in the Victorian education system.

Conducting more research in this field of study related to effective teachers, best practices, the impact of professional development, the impact of gifted programs, and knowing the students' voice, needs to continue to take place, in order to improve the education that Victoria provides for its gifted and talented students.

\section{References}

American Psychological Association [APA] (2015). Top 20 principles from psychology for preK-12 teaching and learning. Retrieved from http://www.apa.org/ed/schools/cpse/t op-twenty-principles.pdf

American Psychological Association [APA] (2017). Top 20 principles from psychology for preK-12 creative, talented, and gifted students' teaching and learning. Retrieved from http://www.apa.org/ed/schools/teachi ng-learning/top-twenty-principles.aspx

Association for Gifted and Talented Education Victoria [AGATEVIc]. (n.d.). Mambership categories. Retrieved from https://sites.google.com/agatevic.org/ website $/$ membership?authuser $=0$

Assouline, S. G., Colangelo, N., \& VanTasselBaska, J. (2015). A nation empowered: Evidence trumps the excuses holding back America's brightest students (Vol. I). Iowa City, IA: The Connie Belin \& Jacqueline
N. Blank International Center for Gifted Education and Talent Development, University of Iowa.

Assouline, S. G., Marron, M., \& Colangelo, N. (2014). Acceleration: The fair and equitable intervention for highly able students. In J. A. Plucker, \& C. M. Callahan (Eds.), Critical issues and practices in gifted education: What the research says (pp. 15-28). Texas: Prufrock Press Inc. https://d oi.org/10.1080/02783193.2015.975776

Australian Association for the Education of the Gifted and Talented [AAEGT]. (n.d.). About AAEGT. Retrieved from http://www .aaegt.net.au/?page_id $=724$

Australian Curriculum. (2018). Student diversity. Retrieved from https://www.australiancurri culum.edu.au/resources/student-diversity/

Australian Curriculum Assessment and Reporting Authority [ACARA]. (2016). Student diversity. Retrieved from http://www .acara.edu.au/curriculum/student-diversity

Australian Government. (2018). State and territory government. Retrieved from https://www.australia.gov.au/about-g overnment/how-government-works/state-a nd-territory-government

Australian Institute for Teaching and School Leadership. (2017). Australian professional standards for teachers. Retrieved from https: //www.aitsl.edu.au/teach/standards

Cabrera-Murcia, E. P. (2012). What must we know and know how to do for implementation during the PENTAUC school program? A view from the teachers. Universitas Psychologica, 11(3), 815-827.

Catholic Education Office Melbourne. (2013). Gifted and talented students: A resource guide for teach in Victorian Catholic schools. Retrieved from https://www.cem.edu.au/CatholicEdu cationMelbourne/media/Documentation/ Documents/Gifted-and-Talented-handboo k.pdf

Cross, T. L., Andersen, L., \& Mammadov, S. (2015). Effects of academic acceleration on the social and emotional lives of gifted students. In S. G. Assouline, 
N. Colangelo, J. VanTassel-Baska, \& A. Lupkowski-Shoplik (Eds.), A nation empowered: Evidence trumps beliefs that hold back America's brightest students (Vol. II, pp. 31-42). Iowa City, IA: The Connie Belin \& Jacqueline N. Blank International Center for Gifted Education and Talent Development, University of Iowa.

Dare, L., Smith, S., \& Nowicki, E. (2016). Parents' experiences with their children's grade-based acceleration: Struggles, successes, and subsequent needs. Australasian Journal of Gifted Education, 26(2), 6-21. https://doi.org/10.21505/ajge.2 016.0012

Davis, G. A., Rimm, S. B., \& Siegle, D. (2011). Education of the gifted and talented. New Jersey: Pearson.

Department of Education and Training, Victoria. [DET] (2017a). Early entry to school. Retrieved from http://www.education.vic.g ov.au/school/parents/learning/Pages/gifted earlyentry.aspx

Department of Education and Training, Victoria. [DET] (2017b). Accelerated learning options: FAQs. Retrieved from http://www. education.vic.gov.au/school/parents/learni ng/Pages/giftedacceleratedfaqs.aspx

Department of Education and Training, Victoria. [DET] (2017c). Teach gifted and talented students. Retrieved from http://www.educa tion.vic.gov.au/school/teachers/learningne eds/Pages/gifted.aspx

Department of Education and Training, Victoria. [DET] (2017d). School-based opportunities for gifted students. Retrieved from http://www.education.vic.gov.au/scho $\mathrm{ol} /$ parents/learning/Pages/giftedschoolopps. aspx

Department of Education and Training, Victoria. [DET] (2018a). About the schools Retrieved from http://www.education.vic.gov.au/scho ol/parents/secondary/Pages/aboutschools.a spx

Department of Education and Training, Victoria. [DET] (2018b). Learning in the early years: Gifted and talented children. Retrieved from http://www.education.vic.gov.au/chil
dhood/professionals/learning/Pages/gtmake difference.aspx

Department of Education and Training, Victoria. [DET] (2018c). Finding your school's funding. Retrieved from http://www.education.vic.gov.au/abo ut/educationstate/Pages/schoolbudget.aspx

Directorate of School Education. (1995). Bright Futures. A policy statement to support gifted students. Melbourne. Australia.

Frantz, R. S., \& McClarty, K. L. (2016). Gifted education's reflection of country-specific cultural, political, and economic features. Gifted and Talented International, 31(1), 46-58. https://doi.org/10.1080/15332276.2 016.1220794

Fraser-Seeto, K., Howard, S., \& Woodcock, S. (2015). An investigation of teachers' awareness and willingness to engage with self-directed professional development package on gifted and talented education. Australian Journal of Teacher Education, 40(1), 1-14. https://doi.org/10.14221/ajte.2 $015 \mathrm{v} 40 \mathrm{n} 1.1$

Gagné, F. (1985). Giftedness and talent: Reexamining a reexamination of the definitions. Gifted Child Quarterly, 29, 103112.

Gagné, F. (2005). From gifts to talents: The DMGT as a developmental model. In R. J. Sternberg \& J. E. Davidson (Eds.), Conceptions of giftedness, second edition (pp. 98-119). New York, NY: Cambridge University Press.

Gagné, F. (2008). Debating giftedness: Pronat vs. antinat. In L. Shavinina (Ed.), International handbook on giftedness (pp. 155-198). London: Springer.

Gagné, F. (2010). Motivation within the DMGT 2.0 framework. High Ability Studies, 21(1), 81-99. doi: 10.1080/13598139.2010.525341

Gagné, F. (2013). The DMGT: Changes within, beneath, and beyond. Talent Development $\mathbb{E}$ Excellence, 5(1), 5-19.

Gagné, F. (2018). Academic talent development: Theory and best practices. In S. I. Pfeiffer (Ed.), APA Handbook of Giftedness and 
Talent. (pp. 163-184). Washington, DC: American Psychological Association.

Gagné, F., \& Gagnier, N. (2004). The socioaffective and academic impact of early entrance to school. Roeper Review, 26(3), 128-138. https://doi.org/10.1080/02783190 409554258

Gross, M. U. M., Urquhart, R., Doyle, J., Juratowitch, M., \& Matheson, G. (2011). Releasing the brakes for high-ability learners: Administrator, teacher and parent attitudes and beliefs that block or assist the implementation of school policies on academic acceleration. Retrieved from: https://educati on.arts.unsw.edu.au/media/EDUCFile/Rel easing_the_Brakes_Overview_A4_Nov2 011.pdf

Hirsh, S. (2009). A new definition. Journal of Staff Development, 30(4), 10-6.

International Baccalaureate. (2017). Programmes. Retrieved from https://www.ib o.org/programmes/

Jarvis, J. M., Jolly, J. L., \& Moltzen, R. (2018). Gifted education in Australia and New Zealand: Reflections and future directions. In J. L. Jolly, \& J. M. Jarvis (Eds.), Exploring gifted education: Australian and New Zealand perspectives (pp. 206-211). New York: Routledge.

Johnsen, S. K. (2012). Standards in gifted education and their effects on professional competence. Gifted Child Today, 35(1), 49-57. https://doi.org/10.1177/1076217511 427430

Joyce, S. (2005). An Overview of gifted and talented provisions in Victoria. TalentEd, 1 , 36-41.

Kaman, Y., \& Kronborg, L. (2012). Perceptions of learning at a select entry accelerated high school for high ability students. The Australasian Journal of Gifted Education, 21(2), 47-61. Retrieved from https://www.researchgate.net/publica tion/288096967_Perceptions_of_learning _ at_a_select_entry_accelerated_high_scho ol_for_high_ability_students

Knopfe- (2003). Characteristics, competencies and classroom strategies of effective teachers of gifted and talented students. In L. Kronborg \& S. Knopfelmacher (Eds.), Proceedings from the 9th National Conference of the Australian Association for the Education of Gifted and Talented Students, Sydney, 2002, CD Rom (pp.91-104). Melbourne: AAEGT.

Kronborg, L. (2002). Foreword. In W. Vialle, \& J. Geake (Eds.), The gifted enigma. A collection of articles (pp. vi-xxi). VIC: Hawker Brownlow Education.

Kronborg, L. (2017). Professional learning for teachers who motivate and support diverse gifted and highly able students for talent development: Research on what they know and what works in their teaching. World Council for Gifted and Talented Children's (WCGTC) Conference. Sydney, UNSW.

Kronborg, L. (2018a). Gifted education in Australia and New Zealand. In S. I. Pfeiffer (Ed.), APA Handbook of Giftedness and Talent. (pp. 85-96). Washington, DC: American Psychological Association.

Kronborg, L. (2018b). Cultivating teachers to work with gifted students. In J. L. Jolly, \& J. M. Jarvis (Eds.), Exploring gifted education: Australian and New Zealand perspectives (pp. 82-94). New York: Routledge.

Kronborg, L., \& Meyland, J. (2003). Changes in postgraduate teachers' opinions about gifted students and their education. Proceedings from the 15th World Conference for Gifted Education-Gifted 2003: A Celebration Down Under. Adelaide.

Kronborg, L., \& Plunkett, M. (2012). Examining teacher attitudes and perceptions of teacher competencies required in a new selective high school. The Australasian Journal of Gifted Education, 21(2), 33-46. Retrieved from https://www.researchgate.net/publica tion/285941284_Examining_teacher_attit udes_and_perceptions_of_teacher_compet encies_required_in_a_new_selective_high school

Lassig, C. (2009). Teachers' attitudes toward the gifted: The importance of 
professional development and school culture. Australasian Journal of Gifted Education, 18(2), 32-42. Retrieved from ht tps://eprints.qut.edu.au/32480/

Moltzen, R., Jolly, J. L., \& Jarvis, J. M. (2018). Framing gifted education in Australia and New Zealand. In J.L. Jolly, \& J.M. Jarvis (Eds.), Exploring gifted education. Australian and New Zealand perspectives. (pp. 5-11). New York: Routledge.

Monash University. (2018). Unit selection. Retrieved from https://www.monash.edu/e ducation/current-students/courses/units

Parliament of Victoria. (2012). Inquiry into the education of gifted and talented students. Parliamentary Paper of No.108 Session 2010-2012. Melbourne, Australia: Victorian Government Printer.

Plunkett, M. (2018). Gifted students in rural and remote settings. In J. L. Jolly, \& J. M. Jarvis (Eds.), Exploring gifted education: Australian and New Zealand perspectives (pp. 171-192). New York: Routledge.

Plunkett, M., \& Kronborg, L. (2007). Gifted education in Australia: A story of striving for balance. Gifted Education International, 23(1), 72-83. https://doi.org/10.1177/0261 42940702300109

Plunkett, M., \& Kronborg, L. (2011). Learning to be a teacher of the gifted: The importance of examining opinions and challenging misconceptions. Gifted and Talented International, 26(1-2), 31-46. https://doi.org/10.1080/15332276.2 011.11673587

Pressey, S. L. (1949). Educational acceleration: Appraisal of basic problems. Bureau of Educational Research Monograph, 31. Columbus $\mathrm{OH}$ : The Ohio State University Press.

Rimm, S., Siegle, D., \& Davis, G. (2018) Education of the gifted and talented. New York: Pearson.

Rowley, J. (2012). Professional development needs of teachers to identify and cater for gifted students. The Australasian Journal of Gifted Education, 21(2), 75-80. Retrieved from https://www.researchgate.net/publica
tion/258049515_Rowley_J_2012_Professio nal_development_needs_of_teachers_to_i dentify and cater for gifted students $\bar{A}$ ustralasian_Journal_of_Gifted_Education $212 \quad 75-80$

Senate References Committee. (2001). The education of gifted children. Canberra, Australia: Commonwealth of Australia.

Southern, W. T., \& Jones, E. D. (2004). Types of acceleration: Dimensions and issues. In N. Colangelo, S. G. Aussoline, \& M. U. M. Gross (Eds.), A nation deceived: How schools hold back America's brightest students (Volume I). Retrieved from http://www.accelerationinstitute.org/ Nation_Deceived/Get_Report.aspx

Southern, W. T., \& Jones, E. D. (2015). Types of acceleration: Dimensions and issues. In S. G. Assouline, N. Colangelo, J. VanTasselBaska, \& A. Lupkowski-Shoplik (Eds.) A nation empowered: Evidence trumps beliefs that hold back America's brightest students (Vol. II, pp. 9-18). Iowa City, IA: The Connie Belin \& Jacqueline N. Blank International Center for Gifted Education and Talent Development, University of Iowa.

Southern, W. T., Jones, E. D., \& Stanley, J. C. (1993). Acceleration and enrichment: The context and development of program options. In K. A. Heller, F. J. Monks, \& A. H. Passow (Eds.), International handbook of research and development of giftedness and talent (pp. 387-405). New York: Pergamon.

State of Victoria. (2014). Aiming High. A strategy for gifted and talented children and young people 2014-2019. Department of Education and Early Childhood Development.

The Academy of Accredited SEAL Schools [TAAS]. (2017a). About the SEAL academy. Retrieved from https://www.sealacademy.org.au/inde x.php/about-the-seal-academy

The Academy of Accredited SEAL Schools [TAAS]. (2017b). List of accredited academy SEAL schools. Retrieved 
from https://www.sealacademy.org.au/inde x.php/list-of-academy-seal-schools

The University High School. (2016). Acceleration program enrolment details. Retrieved from http://www.unihigh.vic.edu.au/index. php/enrolments/acceleration-program-seal

VanTassel-Baska, J., \& Johnsen, S. (2007). Teacher education standards for the field of gifted education. Gifted Child Quarterly, 51(2), 182-205. https://doi.org/10.1177/00 16986207299880

Vialle, W., \& Geake, J. (2002). The gifted enigma. A collection of articles. Vic: Hawker Brownlow Education.

Victorian Association for Gifted and Talented Children [VAGTC]. (2016). About us. Retrieved from http://www.vagtc.asn.au/ab out-us

Victorian Curriculum and Assessment Authority [VCAA]. (2017). Higher education studies in the VCE. Retrieved from http://www.vcaa.vic.edu.au/Pages/vce /studies/studiesextension.aspx

Walsh, R. L., \& Jolly, J. L. (2018). Gifted education in the Australian context. Gifted Child Today, 41 (2), 81-88. https://doi.org/1 $0.1177 / 1076217517750702$

Watters, J. J. (2013). Starting small: A staged approach to professional development in gifted education. The Australasian Journal of Gifted Education, 22(2), 5-17. Retrieved from https://eprints.qut.edu.au/67912/

\section{Notes}

i Australia has six states: New South Wales, Queensland, South Australia, Tasmania, Western Australia and Victoria, and two mainland territories Australian Capital Territory and the Northern Territory (Australian Government, 2018). This article focuses on Victoria, a state located in south-eastern Australia.

ii Primary Years Programme (for students between 3-12 years old); Middle Years Programme (11-16 years old): Diploma Programme (16-19 years old); and Careerrelated Programme (16-19 years old) (IB, 2017) iii Language, Second Language, Individuals and Societies, Experimental Sciences, Mathematics and Computer Sciences, Arts and Electives (Davis et al., 2011).

iv "There are two categories. Category 1: Students who have parents with either a Commonwealth Health Care Card or a Pension Card, and who qualify for income support benefits. Category 2: Students who identify as Aboriginal or Torres Strait Islanders on the application form" (DET, 2018a, p. 9).

v Know students and how they learn; know the content and how to teach it; plan for and implement effective teaching and learning; create and maintain supportive and safe learning environments; assess, provide feedback and report on student learning; engage in professional learning; and engage professionally with colleagues, parents/carers and the community (AITSL, 2017).

* Review article. 